\title{
Love in the time of corona
}

\section{Janhavi Shah}

Family Medicine Resident, Rural Maharashtra, India

\begin{abstract}
This is a story about finding joy and love in unexpected times and places. I am a family medicine resident in rural India nearing the end of my training. Family physicians rise to the occasion no matter what. Here, I describe how two of us met and managed a wedding in the midst of a lockdown.
\end{abstract}

Keywords: COVID Personal Story, World Life Balance, COVID 19, Lockdown Doctor's Life

\section{Love in the Time of Corona}

I've spent the last three years doing my residency in Family Medicine at Jan Swasthya Sahyog (JSS), a rural hospital run by a non-profit organization in Ganiyari, a village in Chhattisgarh. While choosing a residency, I knew I wanted to be working in a rural area, I've had my fill of city life, and only a few places offer a holistic rural residency. After a few months here, I realized I was happier than I'd ever been. The clean air, the numerous ponds around, wonderful simple people, and the sense of community a small place has. No traffic, honking, or pollution to be found. I was excited to continue working in such a place in the long run.

It is here that I met my life partner Naman. He joined the hospital last year as a faculty member and there was an instant connection. As fate would have it, we were posted together in the intensive care unit. For once, the long work hours didn't seem so painful. Naman was born in the US where he completed his MD in family medicine and a PhD in epidemiology. During his research, he came across JSS at a conference and stayed in touch with the institution. After he finished his training, he came to work here full time. I'm so glad he did. He is a brilliant doctor who truly

Address for correspondence: Dr. Janhavi Shah, A 1301, Shiv CHS, Opp Croma, Sion, Mumbai - 400 022, Maharashtra, India. E-mail: dr.janhavi.shah@gmail.com

Received: 24-05-2020

Revised: 11-06-2020

Accepted: 14-06-2020

\begin{tabular}{|l|l|}
\hline \multicolumn{2}{c}{ Access this article online } \\
\hline Quick Response Code: & \\
& Website: \\
& www.jmpc.com \\
& \\
&
\end{tabular}

cares for his patients. He is gentle and respectful to everyone: seniors, juniors, friends, and strangers. He is funny and interesting and clever. He does most of the cooking when we're together. While I believe in gender equality, he practices it every day.

We connected over all the little things which matter. Both of us derive joy in walks to the lake, or drives in the jungle, or flipping through a random book of architectural photographs. Spending most of our work hours together brought us closer sooner than we'd expected. It was easy and natural. On one of our walks together, we found three puppies, malnourished, cold, and hungry with no mother in sight. We got them back to campus and started caring for them. As Badal, Bijili, and Barkha grew, so did our bond with each other. Naman's parents were so warm to me, they felt like home from the first day I met them.

Naman and I have been together for over a year now. He proposed three months ago, though he didn't need to ask. The answer was obvious. We set on a ceremony date with both sides of the family for December this year and planned to get a court marriage in February for the interim. Court marriage sounds easy. Unless you belong to two different nationalities and live in a state where neither holds a residence proof. We had two options. Change the address on our Aadhar or get married the Hindu way and present it to the court. Neither option appealed to us. We had been contemplating for a while and being in residency plus the coronavirus epidemic helped us postpone deciding.

This is an open access journal, and articles are distributed under the terms of the Creative Commons Attribution-NonCommercial-ShareAlike 4.0 License, which allows others to remix, tweak, and build upon the work non-commercially, as long as appropriate credit is given and the new creations are licensed under the identical terms.

For reprints contact: WKHLRPMedknow_reprints@wolterskluwer.com

How to cite this article: Shah J. Love in the time of corona. J Family Med Prim Care 2021;10:3176-7. 
Three weeks earlier when doctor deaths due to COVID started surfacing, I started panicking. Maybe this was the end of the world. If it was, I wanted to end as husband and wife. So be it for the court or for COVID, or just my conscience, we agreed on a ceremony. I called Pandit Manisha who was to officiate the December ceremonies and asked if she was comfortable with an online wedding. With her and our parents on board we started planning.

Getting puja items that I've never heard of was a task especially during a lockdown. Luckily, I had my friends Ishani and Soumya to help me with those. Their Maharashtrian names made the translation of words like gandha, phool-vaat, and others easy. Then there was the preparation of the kund. The foreman on campus, Manji bhai, helped us plan how we could safely have the kund at home. We used a metal pan his workers transport sand in as the base and lit the wood, surrounded by a wall of bricks, on it. I had some colorful garden tiles lying around, which made it prettier. The clothes were easy. I'd fallen in love with a Suta saree six months ago that reminded me of Naman and had decided I would wear it when I married him. We didn't have any jewelry, which was perfect and exactly how I wanted it.

A few days before the big day Ishani had the brilliant idea of mehendi. While I disagree with most elaborate traditions and prefer the basic, henna is an exception. The local grocery store had a last batch of cones left and Ishani and a nurse friend Kamini applied mehendi on each hand. While we practiced physical distancing at all stages even till the end, my batchmate and four juniors all crashed in and for a short period of time we were more than five people in a room. We all see each other in the hospital, but that is work, and this meet wasn't necessary. I'm apologetic for that bit.

The morning of the big day, Naman and I made garlands from fresh flowers we plucked on campus and extra surgical suture material. Subhangi, another friend, helped fix my saree when I had failed after one hour of trying. We started on time. The Panditji and our parents were on Skype with our senior mentors from the hospital, Yogesh sir and Rachana ma'am, played the part of the "elders" to physically bless us on our parents behalf during the rituals. Dipankan Jana, our budding surgeon who owns a DSLR, was on photography and Ishani with the rites as she herself was recently wed the Jnana Prabodhini, a progressive movement inspired by Swami Vivekanda, way. Everyone except Naman and I were a meter apart, some even as far as a thousand kilometers.

We had some technical glitches with the computer, much fewer than I expected though. Both moms and dads were attending from Mumbai and Ahmedabad. Pavak and Sapna (Naman's brother and sister-in-law) stayed up beyond midnight and joined from Los Angeles. Extended family started joining in slowly when they heard about it and my dad had accidentally posted the Skype link in a larger family group. As they say, the more the merrier. And merry it was. The rituals went smoothly. We understood the meaning behind everything we were doing. The promises made were not blind. We had discussed writing each other vows after the wedding, as a letter to cherish, but the mantras once translated conveyed everything I would have written. They were so beautiful. After two hours of rites we were done. Our family was on a screen but had never felt closer. The joy and excitement transmitted over the network and between screens. We were together in spirit and that's all that mattered.

We had lunch in the hospital mess as every day. Ram Singh bhaiiya, the master chef of JSS, had kindly made special food to celebrate. Over lunch we met colleagues who congratulated us. It was sweet of them to understand why they could not come home for the ceremony when they lived on the same campus. As I've always said, they are the best. Everyone was happy for us. However frustrating this pandemic has been, especially for healthcare workers, for a change distance could not take away the joy from us. In fact, like Poiseuille's law, I think the distance increased the love we experience from our family and friends. We came back home, changed clothes, spoke to family over the phone, watched some shows, caught up on work, ate cake (my Dipali mami is a magician who had cake delivered to us in these times at a 12 hour notice), walked our dogs, and then let the day sink in.
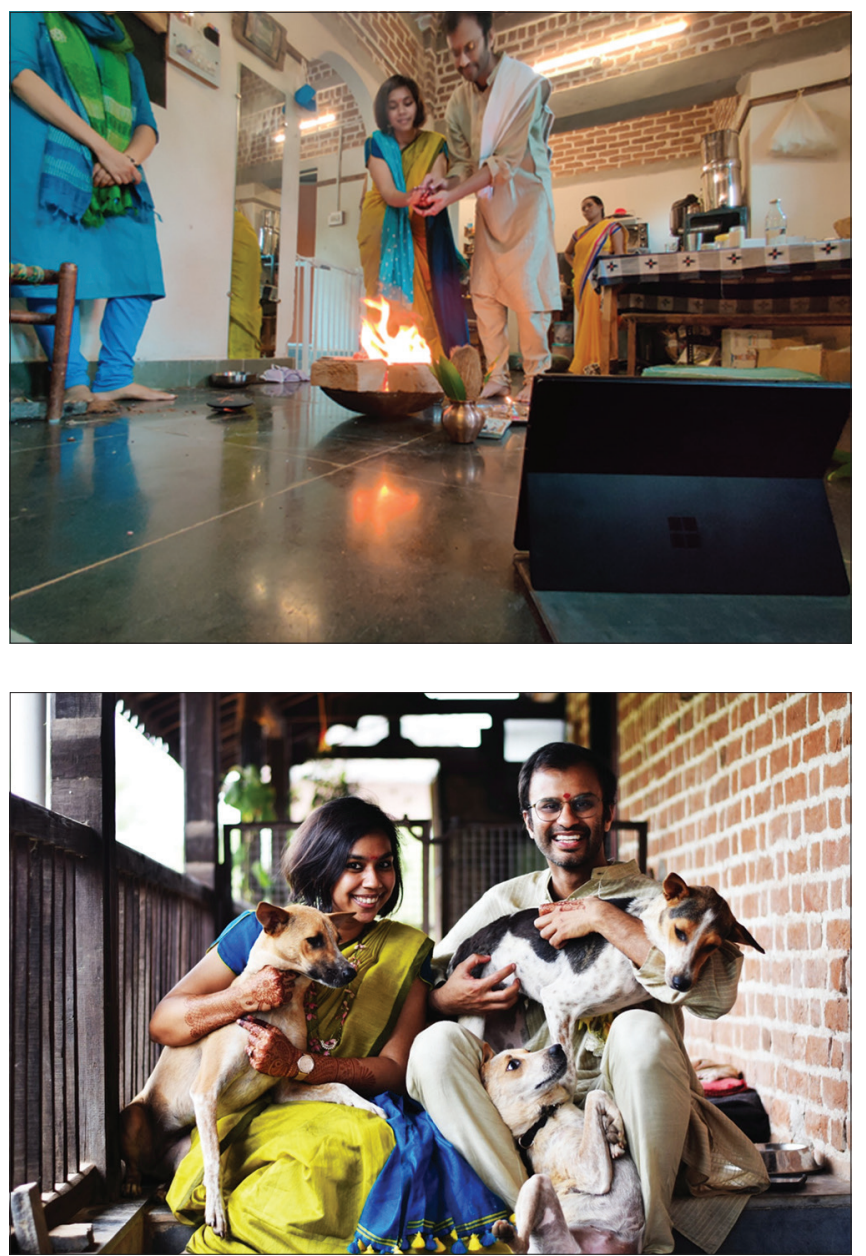